\title{
Creating Shared Value. A Fundamental Critique
}

\author{
Thomas Beschorner 1,* \\ Email thomas.beschorner@unisg.ch \\ Thomas Hajduk 1 \\ Email thomas.hajduk@unisg.ch \\ 1 University of St. Gallen, St. Gallen, Switzerland
}

\section{Abstract}

This article offers a fundamental critique of Michael Porter's and Marc Kramer's "Creating Shared Value" (CSV) concept. First, the authors summarise the positive and negative criticism which CSV has received since 2011. They then show that CSV falls short of a modern understanding of corporate responsibility which is centred on more adequate ideas about the relationship between business and society. The article concludes with critical comments on the role of scholars in their interaction with practitioners.

The following contribution is a translation of the article „Creating Shared Value: Eine Grundsatzkritik“ (2015), published in the Zeitschrift für Wirtschafts- und Unternehmensethik (zfwu) 16 (2): 219-230.

\subsection{Introduction}

"Creating Shared Value" (CSV) - that is what Harvard professors Michael Porter and Mark Kramer (2011) propose. In a well-received article in the Harvard Business Review they recommend a type of value-based management which promises nothing less than the reinvention of capitalism. According to the authors the creation of "shared value" is meant to replace a narrow understanding of management with its rigid fixation on short-term profits. Thus business is thought to regain trust which was lost in the wake of the financial crisis and business scandals. For Porter and Kramer, the objective is to re-integrate and re-embed business into society.

Creating Shared Value has become a buzzword in recent years, in business practice as well as in management theory. Some of its appeal probably owes to its authors' celebrity - and the use of the economic notion of "value". With about 2800 citations in Google Scholar within nearly 5 years, the publication can be classified as highly influential. Although there is no information with regard to the reception of the article, it is fair to assume the reaction to it as mostly positive and approving. The CSV-articles in the Zeitschrift für Wirtschafts- und Unternehmensethik (Vol. 16/No. 2), in which this paper was originally published, also indicate a tendency towards a positive reception of CSV.

However, the approach did receive some criticism as well. One of the first critical reviews was published in The Economist. The commentary was entitled "Oh, Mr Porter" and stated: "[ $\mathrm{t}]$ he new big idea from business's greatest living guru seems a bit undercooked" (Economist 2011) - and that is a rather favourable appraisal of CSV, as we will show. However, virtually no critical voices were heard during the first 2 years after the publication of the CSV-paper. This is quite remarkable. It was only in 2013 and 2014 that a number 
of academic articles criticising CSV were published (cf. Beschorner 2013a; Hartman and Werhane 2013; Crane et al. 2014).

We do not want to review these critical positions in detail, but rather focus on some selected aspects of the discussion. On the basis of this critique, we contrast CSV with a modern understanding of corporate responsibility. We close this article with reflections on the relationship between business and society on the one hand, and the role of social sciences on the other.

\subsection{CSV: Positive and Negative Criticism}

Creating Shared Value aims to re-invent capitalism and thereby to unleash a wave of innovation and growth, from which both businesses and society would profit. Does CSV really live up to this promise? Do Porter and Kramer herald a turnaround in the discussion on business and society? Does their concept obviate Corporate Social Responsibility (CSR)?

Indeed, CSV touches on some progressive ideas. For instance, the authors stress potentially positive contributions of business and focus on them. They hence reject a mere (reputation-based) risk-avoiding, defensive concept. Companies are instead encouraged to "utilize their skills, resources, and management capability to lead social progress" (Porter and Kramer 2011: 77). Even though the understanding of business as a proactive actor has been discussed in the academic literature for some time (cf. Zadek 2001; Beschorner 2004; Matten and Crane 2005; Palazzo and Scherer 2007), this aspect of the article indeed points in a right and important direction.

Furthermore, Porter and Kramer suggest thinking in terms of societal needs - instead of "products" and "services" - and take them as a starting point for innovations. This differentiation is of great importance for companies and their business models, in theory as well as in practice: if you take the need for mobility, then the production and the selling of motor vehicles, for instance, is a means to an end. However, mobility could be provided by other products and services as well (e.g. car sharing, mobility subscription models, etc.). Thus car manufacturers catering to the need for mobility could turn into mobility businesses and develop new, sustainable markets.

While Porter and Kramer seem to be quite progressive regarding these ideas, their orthodox creed becomes apparent in their economic line of argumentation. It is no coincidence that they published their article in the Harvard Business Review and thereby framed it for an audience of business administrators and managers. At the beginning of their paper, they spell out that CSV is neither associated with unwieldy normative terms such as justice, responsibility or the common good, nor related to the known CSR debates, but is rather about a new understanding of the creation of value. With this terminological transition from responsibility to creating value, Porter and Kramer (2014: 150) want to reach a so far sceptical mainstream which otherwise would have continued keeping its distance. The "Shared Value Initiative" booted by their business consultancy "Foundation Strategy Group" invites businesses, civil society and politics to implement the concept in practice.

The attempt to win over CSR sceptics proves to be highly problematic on second thought, though. In particular, Porter and Kramer contrast their CSV with an out-dated understanding of CSR by equating CSR with mere philanthropy that is disconnected from the company's core businesses, while CSV is claimed to be integrated into the core business activities (Porter and Kramer 2011: 76). However, today there is practically nobody who would advocate such a simplistic understanding of CSR, neither in theory, nor in practice (cf. 
Beschorner 2013a). Despite the great multiplicity of CSR definitions in the field, there is a broad consensus about the fact that CSR is not a supplement to business activities but rather an incremental element of a company's core business. Indeed, CSR is not about how businesses spend their profits, but rather about how they make them in the first place. This should have become common currency by now, even in Boston.

Instead, Porter and Kramer re-imagine Corporate Social Responsibility as philanthropy or, in other words, as a straw man (cf. Beschorner 2013a: 109) in order to make their "big idea" plausible. In a special issue on CSV, Crane et al. (2014: 134) criticise the authors for this peculiar notion of CSR. Although Porter and Kramer (2014) give a response to their critics, they do not bother replying on that particular criticism. To make it perfectly clear: we think that this approach is inappropriate in terms of research integrity. If students ignored criticism in similar fashion, they would risk a poor grade. In fact, Porter's and Kramer's critique of CSR hints at how limited the understanding of corporate responsibility still is in mainstream economics. It seems that not much has changed since Milton Friedman's famous New York Times Magazine, according to which CSR is nothing more than philanthropy at the expense of the shareholders (cf. Friedman 1970; for a historical analysis of the article: Hajduk 2015).

Likewise, the authors remain trapped in their neoclassical paradigm when it comes to the remainder of their argumentation. For instance, one-dimensional profit maximization, which CSV has apparently left behind, remains the normative reference point. It is not only presumed that profit maximization is empirically given business needs to maximize profits in a competitive environment - but it is also considered as morally good. CSV reinforces this normative predefinition by assuming that businesses meet "societal needs" while they are generating profits. However, the profit motive alone is questionable, because social needs are seen as a mere means to an end, allowing businesses to discover new market opportunities, to calculate the business case and to invest profitably. Such businesses would be good rational agents, but this behaviour would have nothing to do with genuinely responsible, ethical behaviour. ${ }^{1}$

Even in those cases in which a "shared value" for businesses and society is created, in so called "A-Cases" (cf. Scholz 2014), CSV neither reveals anything new nor can it abandon its purely economic perspective. Crane et al. (2014: 143) and Beschorner (2013a: 110) remind their readers of well-established approaches in management theory (such as stakeholder theory) that consider businesses to be more than just economic agents. They refer to stakeholder theory as a case in point. It had been successful because two of its central premises - business is influenced by society, which is why good management interacts with social groups were compatible with a business-centred economic point of view. CSV takes a similar approach when it responds to societal claims in a purely economic manner. CSV shares a weakness with the stakeholder approach (Beschorner 2013a: 110): business only caters to "relevant" - i.e. influential and powerful stakeholders, but not to other ethically justified claims of "claimholders" (cf. Waxenberger and Spence 2003 ). It therefore fails to achieve true legitimacy.

The economic rationale of the "A-Cases" reaches its limits when a corporation cannot generate any value because business and social interests either do not go hand in hand or are even opposed to each other. In those "B-Cases" CSV does not apply, as Scholz (2014) emphasises (cf. Scholz and des los Reyes 2015). Instead, Porter and Kramer refer to compliance with "laws and ethical standards" (2011: 76) without explicating these standards. This neoclassical idea of rational and profit-driven businesses within a (certainly not too extensively regulated) legal framework points to their limited, rather orthodox understanding of business.

It is correct that businesses are profit-orientated actors and that they operate based on an economic rationality. However, they are also societal actors and as such they understand how to interact with their environment 
through different rationalities (cf. Matten and Crane 2005). They are, for instance, not merely objects of law and order, but also political actors which actively participate in the political decision-making process through lobbying and campaign donations or by engaging in public discourse (cf. Curbach 2009). Businesses can get involved in their communities by acting as "corporate citizens" and thus shaping their social environment.

These activities are not about generating an economic added value for the company; they illustrate rather how businesses assume different roles within society. What we can observe here is that companies follow different rationales or, in other words, speak different languages depending on the context. Pretending that businesses and managers speak only the language of creating (economic) value all the time, Porter and Kramer misconceive business profoundly.

Instead of the functional concept of CSV, businesses need an ethical mission statement on the basis of which they understand themselves not only as economic, but also as societal actors. This touches upon aspects like their fundamental values or their contribution to society. Such a mission statement lays the normative foundation on which businesses can act responsibly. This does not exclude profit maximization. On the contrary, it is the normative foundation that renders profits legitimate in the first place. This legitimacy, and with it the recovery of public trust, is essential for the promised reinvention of capitalism. For this cause though, it is not enough to re-tell the old story of economic rationality, innovation and growth. A real paradigmatic shift requires better ideas and bolder propositions which recognise businesses as a part of society.

\subsection{Modern Corporate Responsibility Is Different}

It should have become quite clear by now that CSV is not a convincing alternative to CSR. On the contrary, it falls short of modern corporate responsibility. But what is meant by "modern corporate responsibility"? First of all, it means to view its supposed weakness - the diversity and at times ambiguity - as a strength. CSR is the conceptual bracket for the discourse on and practice of corporate responsibility. As such, the notion is subject to (historical) change in the same way as other basic terms like "freedom", "democracy" or "public" and necessitates constant (re)definition by discourse. CSR is less about one specific understanding or definition, but rather about a reflection on different ideas and visions of corporate responsibility as well as empirical practices. In our view, the following aspects belong to such a conception of CSR:

First, institutional rules and structures are required in business as well as in society (cf. Wieland 1999). In a liberal, pluralistic society, individual ethics reaches its limits, for example in form of the "honourable merchant". 2 Today's societies are too diverse to be guided only by honour or virtues. Individual ethics therefore has to be complemented by institutional ethics (though not to be replaced by it) (cf. Hajduk and Schank 2015). These institutions, for example in the form of a code of conduct or an advanced value management system, have three functions:

- they relieve individuals of the burden of permanent moral decision-making, which otherwise could overwhelm them;

- clearly defined and transparent rules protect employees against whimsical patriarchs (a potential downside of "honourable merchants"); and

- they signal and communicate both within and outside the company reliable values (e.g. through a corporate philosophy) (cf. Wieland 1999; Gelbman and Baumgartner 2012; Lorentschitsch and Walker 2012). 
Second, purely functionalistic and value-free concepts like CSV are neither normatively appropriate nor empirically accurate. We can observe diverse value orientations in businesses which significantly determine the identity of the respective business. Corporate responsibility needs both to determine these basic values, and to reflect them in a critical and constructive manner.

Implementing such values within the organisation depends on certain capabilities which have to be considered in the empirical analysis and the normative reflection:

- Individual capabilities like (self-) critical thinking, sense of responsibility and (technical) knowledge.

- Organisational capabilities allow for and promote value-oriented behaviour, for example in the form of long-term remuneration models, awareness-building CSR programs, grievance mechanism (e.g. through whistleblowing-systems) or innovation processes which integrate social and ecological considerations.

- Language capabilities for the dialogue with stakeholders are a necessary requirement for creating legitimacy of business activities. The name of the concept "responsibility" points towards such a dialogue that goes beyond strategic stakeholder management and the mere recognition of powerful stakeholders (to which CSV seems to be primarily addressed) (cf. Beschorner 2013a: 110; Crane et al. 2014: 137).

The language-aspect is, thirdly, accompanied by new roles and responsibilities for businesses. Business is not only part of the production system, but rather participates in a wide spectrum of social governance processes which are about the distribution and management of public (global) goods (cf. Wolf and Schwindenhammer 2011). Market transactions and negotiation are only one possible mode of these processes which are already familiar to businesses. There are, however, also other modes such as taking part in societal discourse and deliberative processes.

In this regard, we can observe ever more companies embracing the (political) role as equal partners in publicprivate-partnerships and in co-regulatory initiatives (cf. Beschorner et al. 2013). As a consequence, the relationship between businesses and public actors is changing and growing more complex (cf.

Schmiedeknecht and Wieland 2012). It is no longer only limited to business compliance with government rules, but also includes co-governance and shared responsibility, for example by creating and implementing soft law.

\subsection{Business and Society}

Against the background of our understanding of modern CSR and in line with Crane et al. (2014) we arrive at some fundamental conclusions about business and society. They go beyond the critique of CSV and are essential for a theory of the firm and for business ethics as a whole. To determine the relationship between business and society, it is necessary to develop an appropriate understanding of business and society at first. As for business, neither "as if" constructs, nor theories of normative ethics seem suitable. On the contrary, we need empirical perspectives true to the motto "Corporations ARE what they DO" (Post et al. 2012: 8). With regard to society, we need to develop (from empirical perspectives) a picture of societal contexts that is both a useful theoretical abstraction and sufficiently complex. Preston stated as early as 40 years ago:

serious analysis of the corporation-society relationship requires rigorous and comprehensive conceptions of both the corporation and society; and these conceptions must be articulated in comparable, or at least 
translatable, terms (Preston 1975: 446).

This is important because:

(...) society at large might be interested in performance features of the economic system other than the amount of total current output and its distribution (Preston 1975: 446).

Comparing these paradigmatic observations with Porter's and Kramer's CSV-concept, we see that, firstly, their understanding of business is too reductionist (one-trick pony). Secondly, even though they claim that CSV is oriented towards social questions and they refer to terms such as civil society and regulations, they have an inadequate and theoretically underdeveloped understanding of society. Thirdly, the "translatable terms" (Preston) of CSV are strictly limited to categories of utility, evincing "a very narrow dated notion of what the corporation is" (Crane et al. 2014: 143). The relationship between business and society is thus guided by a purely economic perspective. This economic focus is reflected in the terminology of CSV: "(creating) value" is an economic term that is supposed to replace other - non-economic - business ethics terms such as corporate responsibility or corporate citizen (in the sense of citoyen). Crane et al. pointed out the business-centred perspective of CSV:

to study CSR properly, or for that matter CSV, we cannot start with a notion of what a business is and let its role in society just follow from this (Crane et al. 2014: 143).

Against this backdrop, we hence argued elsewhere:

Porter and Kramer basically tell the old story of economic rationality as the one and only tool of smart management, with faith in innovation and growth, and they celebrate a capitalism that now needs to adjust a little bit. But there is little chance that an increasingly critical civil society will buy into such a story (Beschorner 2013a: 111).

As a result, CSV systematically fails to grasp society's expectations and challenges, because social contexts cannot be understood by exclusively relying on categories of utility.

In this regard, Wieland and Heck (2013: 17) pointed out that the term "shared value" is used in the European Commission's (2011:6) new CSR definition, although it is understood differently from Porter and Kramer:

While Porter/Kramer predominantly focus on businesses and society as a whole, the European Commission stresses that companies recognise stakeholder interests as they integrate CSR into strategic management (Wieland and Heck 2013: 17; our translation).

Wieland and Heck (2015) elaborated on this observation in an email correspondence with the authors of this article:

The normative expectations of government and society must be taken seriously by businesses and need to be addressed, if they want to exist on the market on a long-term basis and generate competitive advantages. Stakeholders of companies are no longer external claimants, but rather constructive elements of everyday business whose interests should be included in business decisions. This normative understanding of 'shared value' has to be distinguished from Porter's and Kramer's concept of 'shared value', whose point of reference is the development of market opportunities for a company. The latter can be a result of the normative 
strategic orientations of a company, but not the limitation of strategy to market development only (our translation).

The problem with the CSV-approach is not only its emphasis on utility, which is also used by strategic stakeholder approaches (cf. e.g. Ulrich 1997: 438ff.; Waxenberger and Spence 2003), but also the businesscentered "framing" of the relationship between business and society, which is prominent in the wider academic literature (including business ethics). It is a perspective on "relationships established between the focal organisation and stakeholders" (Jonker and Foster 2002: 190); the planet "business" is in the centre, stakeholders orbit it as satellites.

We demonstrated elsewhere in more detail (cf. Beschorner 2004, 2013b) that a theoretically and empirically appropriate understanding of the relationship between business and society requires a research perspective that examines the constellations and interactions of actors. We think that neither the distinction between a constitutional and an extra-constitutional level (rules of the game and playing the game), nor the analysis of (merely bilateral) stakeholder relationships are sufficient in this regard.

This perspective is accompanied by a shift from a "society-oriented theory of the firm to a business-oriented theory of society" (Beschorner 2004), which draws on sociological neo-institutionalism and the concept of the "organisational field" (cf. Powell and DiMaggio 1991, 1983). On the one hand, a "business-oriented theory of society" extends the planet-satellite-model of the stakeholder approach. On the other, it clarifies the distinction between "the rules of the game" and "playing the game". It no longer assumes that the rules of the game are solely prescribed from the outside, but quite often result from communication and negotiation processes between regulating and regulated organisations, as Edelman and Suchman (1997: 507) demonstrate.

In this perspective, businesses (and other organisations) are seen as active co-creators of the rules of the game and therefore as subjects of regulatory (co-) responsibility (cf. in more detail Beschorner 2004; Beschorner and Schank 2012). Through the lens of organisational fields businesses are located within society and can thereby be addressed as societal and governance actors in the first place.

\section{5. ... and the Role of Social Sciences}

No, Porter and Kramer are not exactly modest. CSV - and by no means CSR - had led to "substantial changes in behaviour of corporations around the world", they claim (Porter and Kramer 2014: 149). CSV had understood the world, as it really is:

it aligns social progress with corporate self-interest in a concrete and highly tangible way, including with those 'old strategy models' that capture the reality of competition and prevailing corporate practice (ibid.: $150)$.

Not to mention its empirical validity, this telling remark on the (presumed) practice raises the question concerning the role and responsibility of scholars in the discourse with practitioners. We can acknowledge that by using the formulation of "creating value" instead of "responsibility" or even "ethics" Porter and Kramer not only do good (self-) marketing, but possibly also set the right tone in order to be heard by "practitioners". At the same time and given their influence in management, such statements reinforce those economic practices which they had previously identified as risks to the legitimacy of capitalism. Porter and 
Kramer thus give their scholarly blessing to a system they consider besieged due to its mode of operation so far.

Like Dyllick (2014) we could accept this as part of the "ambiguity" that is probably shared by all scholars in business ethics. On the one hand, they do discuss the limitations of concepts like CSV within academic contexts (such as conferences and publications) and thus in the interaction with peers. On the other hand, they emphasise the "business case", reputational gains, competitive advantages etc. when teaching students and particularly practitioners in order to better relate to this audience. Yet even if this was true for most of executive education and even general university teaching, it raises the question why the current state of the art in the business ethics debate should not be taught. Do seasoned professionals and managers lack the ability to tackle topics and questions that challenge their cherished views? Should business ethics scholars take the path of least resistance and ignore fundamental questions of responsibility in favour of easily digestible contents and feel-good seminars?

We do not deny that especially executive education needs substantiation of theoretical positions and scholarly concepts in order to be useful to practitioners. However, there is a big difference whether we talk about practical instruments and adequate processes by which responsibility can be implemented or whether we sell an intellectual snake oil and thereby deny business people's moral responsibilities and reflective capabilities.

Dealing with issues and solutions in business ethics is challenging, both for scholars and practitioners. However, we need to face these challenges with suitable concepts. CSV is not one of them.

\section{References} AQ1

Beschorner, Thomas. 2004. Unternehmensethische Untersuchungen aus gesellschaftlicher Perspektive. Von der gesellschaftsorientierten Unternehmenslehre zur unternehmensorientierten Gesellschaftslehre. Zeitschrift für Wirtschafts- und Unternehmensethik 5(3): 255-276.

. 2013a. Creating shared value: The one-trick pony approach - a comment on Michael Porter and Mark Kramer. Business Ethics Journal Review 1(17): 106-112.

2013b. Kulturalistische Wirtschaftsethik: Grundzüge einer Theorie der Anwendung. Zeitschrift für Wirtschafts- und Unternehmensethik 14(3): 346-372.

Beschorner, Thomas, and Thomas Hajduk. 2012. Vom ehrbaren Kaufmann zur Unternehmensverantwortung. Forum Wirtschaftsethik Online 2: 2-7.

Beschorner, Thomas, and Christoph Schank. 2012. CSR - zur Bürgerrolle und Verantwortung von Unternehmen. In Corporate social responsibility: verantwortungsvolle unternehmensfühung in Theorie und Praxis, ed. A. Schneider, and R. Schmidpeter, 155-164. Berlin: Springer.

Beschorner, Thomas, Thomas Hajduk, and Samuil Simeonov (ed). 2013. Corporate responsibility in Europe. Government involvement in sector-specific initiatives. Gütersloh: Verlag Bertelsmann Stiftung.

Crane, Andrew, Guido Palazzo, Laura J. Spence, and Dirk Matten. 2014. Contesting the value of the shared 
value concept. California Management Review 56(2): 130-153.

Curbach, Janina. 2009. Die Corporate-social-responsibility-bewegung. Wiesbaden: VS Verlag für Sozialwissenschaften.

Donaldson, Thomas. 2014. Shared values that are lost in translation. Financial Times, April 23.

Dyllick, Thomas. 2014. The opposing perspectives on creating shared value. Financial Times, April 24.

Edelman, L.B., and M.C. Suchman. 1997. The legal environments of organizations. Annual Review of Sociology 23(1): 479-515.

European Commission. 2011. A renewed EU strategy 2011-14 for Corporate Social Responsibility. Access to European Union law. http://eur-lex.europa.eu/legal-content/EN/TXT/PDF/?uri=CELEX:52011DC0681\& from=EN . Accessed 29 Oct 2015.

Friedman, Milton. 1970. A Friedman doctrine - The social responsibility of business is to increase its profits. The New York Times Magazine, September 13.

Gelbman, Ulrike, and Rupert J. Baumgartner. 2012. Strategische implementierung von CSR in KMU. In Corporate Social Responsibility, ed. A. Schneider, and R. Schmidpeter, 285-298. Berlin: Springer.

Hajduk, Thomas. 2014. Stichwort: Ehrbarer Kaufmann. Stichwortverzeichnis: CSR NEWS http://csr-news.net /main/2014/03/23/ehrbarer-kaufmann . Accessed 29 Sep 2015.

Hajduk, Tomas. 2015. Bei Friedman nichts Neues. Anmerkungen zu einem falsch verstandenen Klassiker der CSR-Diskussion. In Markt und Verantwortung. Wirtschaftsethische und moralökonomische Perspektiven, ed. D. Aufderheide, and M. Dabrowski, 89-98. Berlin: Duncker \& Humblot.

Hajduk, Thomas, and Christoph Schank. 2016. The model of the honourable merchant: Bridging compliance and integrity? In Handbook of virtue ethics in business and management, ed. A.J.G. Sison. Berlin and Heidelberg: Springer (in press).

Hartman, L.P., and P.H. Werhane. 2013. Shared value as an incomplete mental model. Business Ethics Journal Review 1(6): 36-43.

Jonker, Jan, and David Foster. 2002. Stakeholder excellence? Framing the evolution and complexity of a stakeholder perspective of the firm. Corporate Social Responsibility and Environmental Management 9(4): $187-195$.

Lorentschitsch, Bettina, and Thomas Walker. 2012. Vom integrierten zum integrativen CSR-Managementansatz. In Corporate social responsibility, ed. A. Schneider, and R. Schmidpeter, 299-316. Berlin: Springer.

Matten, Dirk, and Andrew Crane. 2005. Corporate citizenship: Toward an extended theoretical conceptualization. Academy of Management Review 30(1): 166-179. 
Palazzo, Guido, and Andreas G. Scherer. 2007. Toward a political conception of corporate responsibility: Business and society seen from a Habermasian perspective. Academy of Management Review 32(4): 1096-1120.

Porter, M.E., and M.R. Kramer. 2011. Creating shared value. How to Re-invent capitalism - and unleash a wave of innovation and growth. Harvard Business Review 89(1): 62-77.

. 2014. A Response to Andrew Crane's et al.'s article. California Management Review 56(2): $149-151$.

Post, James E., Lee E. Preston, and Sybille Sachs. 2012. Redefining the corporation. Stakeholder management and organizational wealth. Stanford: Stanford University Press.

Powell, Walter W., and Paul DiMaggio (ed). 1991/1983. The new institutionalism in organizational analysis. Chicago/London: The University of Chicago Press.

Preston, Lee E. 1975. Corporation and society: The search for a paradigm. Journal of Economic Literature 13(2): 434-453.

Schmiedeknecht, Maud H., and Josef Wieland. 2012. ISO 26000, 7 Grundsätze, 6 Kernthemen. In Corporate social responsibility, ed. A. Schneider, and R. Schmidpeter, 259-270. Berlin: Springer.

Scholz, Markus. 2014. Stichworte: Creating shared value, shared value. Stichwortverzeichnis: CSR NEWS http://csr-news.net/main/2014/03/23/creating-shared-value-2 . Accessed 29 Sep 2015.

Scholz, Markus, and Gaston de los Reyes. 2015. Creating shared value - Grenzen und Vorschläge für eine Weiterentwicklung / Creating shared value - limits and suggestions for further development. Zeitschrift für Wirtschafts-und Unternehmensethik 16(2): 192-202.

The Economist. 2011. Oh, Mr Porter. The Economist, March 10.

Ulrich, Peter. 1997. Integrative Wirtschaftsethik. Grundlagen einer lebensdienlichen Ökonomie. Haupt Verlag: Bern/Stuttgart/Wien.

Waxenberger, Bernhard, and Laura J. Spence. 2003. Reinterpretation of a Metaphor: from stakes to claims. Strategic Change 12(5): 239-249.

Wieland, Josef. 1999. Die Ethik der governance. Marburg: Metropolis.

Wieland, Josef, and Andreas E.H. Heck. 2013. Shared value durch stakeholder governance. Marburg: Metropolis.

. 2015. Creating Shared Value: E-Mail correspondence with Thomas Beschorner and Thomas Hajduk from 7 Jan 2015.

Wolf, Klaus D., and Sandra Schwindenhammer. 2011. Vom business case zum public case? Der Beitrag privater Selbstregulierung zu Global Governance. Zeitschrift für Wirtschafts- und Unternehmensethik 12(1): 
$10-28$.

Zadek, Simon. 2001. The civil corporation: The new economy of corporate citizenship. London: Routledge.

We therefore characterized CSV in a different publication as a "One-Trick Pony Approach" (cf. Beschorner 2013a).

2 Cf. description and examples of the concept in Hajduk (2014) and a fundamental critique in Beschorner and Hajduk (2012). 